\title{
La recerca en aprenentatge de llengües i les percepcions sobre les pràctiques didàctiques a l'aula: el cas de l'ensenyament dels passats en català com a llengua addicional
}

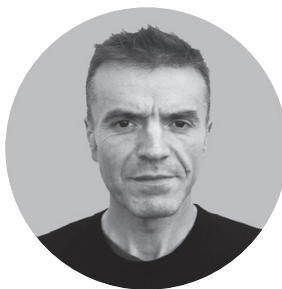

LLORENÇ COMAJOAN-COLOMÉ

UNIVERSITAT DE VIC-UNIVERSITAT CENTRAL DE CATALUNYA

1lorenc.comajoan@uvic.cat

\begin{abstract}
A quest article té un doble objectiu. D'una banda, es fa un repàs a la relació complexa que hi ha hagut entre la recerca en l'ensenyament-aprenentatge de llengües addicionals a persones adultes i les pràctiques a l'aula. Es presenten les diferents posicions que hi ha hagut al voltant del debat i les tendències actuals. D’altra banda, s'il-lustra la relació entre la recerca i la pràctica a partir d'un estudi sobre les percepcions del professorat de català com a llengua addicional pel que fa a la influència de la recerca en les seves percepcions de pràctiques a l'aula. L'estudi es basa en les respostes a un qüestionari en línia que van contestar 76 docents de català per a persones adultes als territoris de llengua catalana i a l'exterior. El qüestionari incloïa una pregunta oberta en què es demanava als docents si pensaven que la recerca en didàctica de la llengua havia influït la seva manera d'ensenyar els usos i formes del passat en català. Els resultats de l'estudi van mostrar que la meitat dels docents van dir que havien rebut influència de la recerca en les seves pràctiques a l'aula. Els docents van relacionar la influència de la recerca més amb aspectes metodològics de l'ensenyament de llengües (l'enfocament comunicatiu) i de la pròpia experiència que no pas amb temes concrets de recerca. Al final de l'article es plantegen diferents maneres de consolidar el camp de la recerca en la didàctica del català com a llengua addicional per a persones adultes.
\end{abstract}

\section{PARAULES CLAU:}

rellevància de la recerca; compromís amb la recerca; creences del professorat; català com a llengua addicional comis is article has a dual purpose. On the one hand, it reviews the complex relationship between research into the teaching and learning of additional languages to adults and classroom practice. The different positions that have existed around the current debate and trends are presented. On the other hand, the relationship between research and practice is illustrated from a study on the perceptions of teachers of Catalan as an additional language in terms of the influence of research on their perceptions of practices in the classroom. The study is based on the answers to an online questionnaire answered by 76 Catalan teachers for adults in Catalan-speaking territories and abroad. The questionnaire included an open-ended question in which teachers were asked if they thought that research in language teaching had influenced their way of teaching the meanings and forms of the past in Catalan. The results of the study showed that half of the teachers said they had been influenced by research in their classroom practices. Teachers related the influence of research more to methodological aspects of language teaching (the communicative approach) and their own experience than to specific research topics. At the end of the article, different ways of consolidating the field of research in the teaching of Catalan as an additional language for adults are proposed.

KEYWORDS:

relevance of research; research engagement; teacher beliefs; Catalan as an additional language 


\section{Recerca i pràctica en l'ensenyament de llengües addicionals a persones adultes: les disciplines que hi intervenen}

L es disciplines acadèmiques que intervenen en l'estudi del procés d'ensenyar-aprendre llengües addicionals són diverses i inclouen, entre altres, la lingüística aplicada, la didàctica de la llengua i l'adquisició de llengües addicionals. En aquesta secció es fa un repàs a l'origen i a la complexa delimitació de les diferents disciplines per tal de mostrar el desenvolupament de les relacions entre la recerca i la pràctica docent. En aquest repàs ens centrem en els canvis globals de les disciplines i en la manera com s'han plasmat a la realitat educativa de l'ensenyament del català com a llengua addicional per a persones adultes.

La relació entre la recerca i la pràctica en l'ensenyament de llengües va lligada a l'evolució epistemològica de les diferents disciplines que han intervingut en l'ensenyament de llengües. Dins la tradició de les llengües romàniques, la disciplina que estudia l'ensenyament-aprenentatge de llengües a l'aula s'anomena Didàctica de la llengua (DL), nom que ve del grec antic didaskein ("ensenyar", "instruir") i tekne ("art", "tècnica"). ${ }^{2}$ Com a disciplina consolidada, la DL és una disciplina relativament jove que es va constituir a Espanya arran d'una sèrie de canvis legislatius i educatius als anys 80, com ara la reforma educativa de la LOGSE (1990). López Valero i Encabo Fernández (2013) esmenten que va ser l'any 1986 quan es va reconèixer la didàctica de la llengua i la literatura com a àrea de coneixement i que abans d'aquell any era la disciplina de la filologia la que tradicionalment s'havia ocupat de l'ensenyament de llengües. La constitució de la disciplina té a veure també amb el desenvolupament de la història de la lingüística $i$, més en concret, de la lingüística aplicada durant el segle XX. Mentre que la lingüística tradicionalment s'havia interessat per la descripció i explicació de la manera com s'estructuren les llengües i la facultat humana del llenguatge, la lingüística aplicada es va centrar a resoldre problemàtiques concretes relacionades amb la llengua. I el repte que va afrontar de manera focalitzada la lingüística aplicada en la seva constitució i desenvolupament, a partir dels anys 70 del segle $\mathrm{XX}$, va ser l'ensenyament de llengües.

\section{${ }^{66}$ La relació entre la recerca $i$ la pràctica en l'ensenyament de llengües va lligada a l'evolució epistemològica de les diferents disciplines que han intervingut en l'ensenyament de llengües.'}

Camps (2012, p. 23) defineix la DL de la manera següent: "un camp de coneixement que té com a objecte el complex procés d'ensenyar i aprendre llengües amb la finalitat de millorar les pràctiques $i$ adequar-les a les situacions canviants en què es desenvolupa aquesta activitat" (traducció nostra del castellà). Com es pot observar a la definició, la DL té una finalitat pràctica, però això no implica que aquesta finalitat sigui l'única funció de la DL. Com esmenta la definició, la DL també constitueix un camp de coneixement concret o disciplina que estudia el procés d'ensenyar-aprendre llengües. En concret, la DL s'encarrega d'estudiar el sistema didàctic integrat per: a) una matèria (la llengua), b) l'alumnat i c) el docent. A més, la DL no se centra a ensenyar continguts de llengua, sinó que se centra en els alumnes i els processos que segueixen durant la intervenció per aprendre llengua (Mendoza i Cantero, 2013; Camps, 2000; 2012). En aquest sentit, el concepte de transposició didàctica és al cor de la DL. La transposició didàctica és el procés pel qual es transformen objectes del saber (per exemple, en català es fa una distinció entre les formes perfectives i imperfectives del verb en temps passat: "vaig córrer", "corria") en objectes d'ensenyament (com s'aprenen i s'ensenyen les formes i usos dels verbs del passat a l'aula?). Com que intervenen diferents agents en el sistema didàctic (matèria, alumnat $\mathrm{i}$ docents), la DL és interdisciplinària $\mathrm{i}$ es relaciona amb la lingüística, la psicologia i la pedagogia, entre d'altres. És a dir, és una disciplina aplicada, la qual cosa no implica que no hagi desenvolupat la seva pròpia teoria (vegeu Camps, 2012; Dolz, Gagnon i Mosquera, 2009; Mendoza i Cantero, 2013; López Valero i Encabo Fernández, 2013, per a discussions epistemològiques sobre la DL). ${ }^{3}$

La configuració de les disciplines relacionades amb l'ensenyament de llengües es fa més complexa perquè a mitjans del segle XX va emergir una altra disciplina d'estudi centrada a estudiar temes vinculats amb la lingüística $\mathrm{i}$ l'ensenyament de llengües: l'anomenada second language acquisition o "adquisició de segones llengües" (ASL). ${ }^{4}$ Aquesta disciplina va sorgir dins de la lingüística aplicada, sobretot en l'entorn anglosaxó, i als inicis es va interessar en particular per l'ensenyament de llengües. Amb el temps, però, s'ha diversificat i hi conviuen un nombre considerable de teories sobre els processos cognitius i socials que intervenen en l'aprenentatge de llengües. ${ }^{5}$ La disciplina de l'ASL s'ha consolidat dins del món anglosaxó i per això existeixen departaments universitaris d'ASL, càtedres d'ASL, publicacions acadèmiques d'ASL, congressos d'ASL, etc. En canvi, en l'entorn acadèmic romànic, la denominació d'ASL no s'ha consolidat i, si hi és present, sol anar lligada a departaments universitaris de filologia anglesa $\mathrm{i}$ didàctica de la llengua anglesa. En l'entorn romànic, els temes que tracta l'ASL solen quedar repartits entre les disciplines de la lingüística, la lingüística aplicada i la DL. El resultat és que mentre que la disciplina d'ASL s'ha especialitzat en l'estudi d'un nombre considerable de temes teòrics i pràctics sobre els processos d'aprenentatge de llengües (adquisició de sintaxi, morfologia, pragmàtica; influència de la instrucció implícita i explícita, etc.), aquests mateixos temes han quedat repartits en diferents disciplines en el context de recerca català. Això 
pot ser vist com un avantatge i un inconvenient alhora. És avantatjós perquè el procés d'aprenentatge d'una llengua és necessàriament interdisciplinari. És perjudicial perquè el coneixement queda fragmentat i no hi ha una sola disciplina que aglutini investigadors al voltant d'un procés.

Recentment, en l'esfera anglosaxona, hi ha hagut un debat al voltant d'una "nova" (sub)disciplina de l'ASL, l'anomenada instructed second language acquisition (ISLA) o "adquisició instruïda de segones llengües". Tal com indica el nom, s'encarrega d'estudiar l'aprenentatge d'una llengua addicional en un context d'instrucció, és a dir, principalment a l'aula i de manera explícita. En concret, Loewen (2020, pp. 2-3) va definir l'ISLA de la manera següent:

Instructed Second Language Acquisition is a theoretically and empirically based field of academic inquiry that aims to understand how the systematic manipulation of the mechanisms of learning and/or the conditions under which they occur enable or facilitate the development and acquisition of an additional language.

“L'Adquisició Instruïda de Segones Llengües és un camp de base teòrica i empírica que té com a objectiu investigar com la manipulació sistemàtica dels mecanismes d'aprenentatge i/o les condicions en què tenen lloc permeten o faciliten el desenvolupament $\mathrm{i}$ l'adquisició d'una llengua addicional'. (Traducció de l'autor de l'article)

Per a Loewen (2020), l'ISLA té tres requisits: a) instrucció, és a dir l'ensenyament-aprenentatge té lloc en un context en què hi ha un intent sistemàtic de manipular les condicions d'aprenentatge, b) nivell de consciència que s'està aprenent una llengua per part de l'alumnat i c) recerca empírica amb evidències sobre el resultat (aprenentatge) a partir de la manipulació a l'aula per veure l'impacte que té en l'aprenentatge (vegeu Leow i Cerezo, 2016 per a matisos en aquesta definició). L'èmfasi en la constitució d'una nova disciplina com l'ISLA en el context anglosaxó sembla una reacció al fet que en anys anteriors la disciplina de l'ASL s'havia desmarcat dels aspectes centrats en l'aula i en la intervenció didàctica —que s'havien relegat als estudis centrats en educació i pedagogia. Ara bé, en el context romànic, podríem considerar que, des de la constitució de la DL com a disciplina als anys 80 del segle XX, la DL ja tenia en compte tant els aspectes més teòrics com els pràctics $i$, per això, pot semblar redundant parlar de l'ISLA com una nova disciplina. ${ }^{6}$

L'estatus epistemològic de l'ISLA encara està en discussió $\mathrm{i}$ hi ha diferents maneres de veure com es relaciona $\mathrm{amb}$ l'ASL i, de retruc, amb la DL. Tot i que el terme instructed second language acquisition s'utilitza des de fa més de 25 anys (per exemple, Ellis, 1991; Housen i Pierrard, 2005), és a partir de 2015 que es va consolidar la disciplina i el debat sobre el seu estatus (Leow, 2015; 2020; Loewen i Sato, 2019; Leow i Cerezo, 2016; Long, 2017). La consolidació de la disciplina queda palesa amb el fet que una revista de recerca hi està del tot dedicada: Journal of Instructed Second Language Acquisition. L'interès per l'ISLA també es pot relacionar amb el creixent interès per les pràctiques basades en evidències (Sato i Loewen, 2019; DeKeyser i Prieto Botana, 2019).

El desenvolupament de les disciplines que acabem de resumir fa que l'estudi de la relació entre la recerca i la pràctica en l'ensenyament de llengües sigui complex i ric alhora. D'una banda, continua existint una tensió subjacent, que porta a una diversitat de teories inassolible (Ortega, 2015; Van Patten, Keating, i Wulff, 2020) o a la possible fragmentació de la disciplina de l'ASL (DeKeyser, 2010). D'altra banda, es fa palès l'interès en els processos d'ensenyament-aprenentatge de llengües i la collaboració entre investigadors i disciplines. En el món anglosaxó, el debat entre recerca i pràctica en l'ensenyament de llengües a persones aultes s'ha dut a terme sobretot dins de la disciplina de l'ASL i s'ha debatut abastament fins a quin punt la disciplina de l'ASL ha d'incloure o no temes didàctics. En el món romànic, el debat ha estat menys intens i sovint s'ha dut a terme dins de la disciplina de la DL (cf. Lacorte, 2014; Simard et al., 2010; Rastelli, 2009). En el cas de l'ensenyament del català, el debat entre recerca i pràctica s'ha concentrat en la formació de docents d'educació obligatòria (infantil, primària i secundària), tant en el cas de primeres llengües com les addicionals, mentre que en l'àmbit de l'ensenyament de català com a llengua addicional per a persones adultes el debat és escàs. En la formació de docents de primària i secundària, s'ha tendit a adoptar un model basat en la pedagogia crítica i el socioconstructivisme, la importància de la reflexió crítica per part dels docents a partir de les seves experiències i la recerca a l'aula (per exemple, Aguilar, 2001; Camps, Ríos, i Cambra, 2000; Esteve, 2011; 2013; Esteve, Fernández, Martín-Peris, i Atienza, 2017 i els estudis d'aquest monogràfic). En la formació de docents de català com a llengua addicional per a persones adultes, la discussió al voltant de la recerca i la pràctica s'ha concentrat en els enfocaments metodològics per al disseny de cursos de català i en menor grau en la formació del professorat (Bori, 2020; Comajoan, 1999; Gimeno, 2007; 2012; Lacueva, 2017).

En resum, durant els darrers 40 anys, des de l'inici de la DL i l'ASL com a disciplines autònomes, hi ha hagut un estira $i$ arronsa sobre el focus de cada disciplina a l'hora de delimitar el seu camp d'estudi. Si bé als inicis semblava que hi havia un interès a delimitar clarament què estudiava cadascuna, en l'actualitat hi ha més permeabilitat i treball interdisciplinari. Les possibles tensions entre les disciplines han estat motiu d'estudi i es tracten en l'apartat següent.

\section{Estudis sobre l'impacte de la recerca en l'ensenyament de llengües}

7 interès per la relació entre la recerca i la pràctica i la influència d'una sobre l'altra en l'ensenyament de llengües ha fet que hi hagi un nombre considerable d'obres que tracten el tema de manera directa (Comajoan, 1999; 2004; 2015; Ellis i Shintani, 2014). A grans trets, els estudis que investiguen la relació són de dos tipus: assagístics i empírics. 


\subsection{Estudis assagístics}

Les aportacions en forma d'assaig tracten la relació entre la recerca i la pràctica en l'ensenyament de llengües a partir de l'exposició i argumentació de les principals idees al voltant del tema. En general, les obres d'aquest tipus no aporten dades empíriques originals, sinó que se solen centrar en l'argumentació d'idees i, en tot cas, en dades d'estudis anteriors. Inicialment, aquestes publicacions pressuposaven una perspectiva unidireccional o aplicacionista, és a dir es basaven en la idea que la recerca havia de delimitar la manera com s'havia d'implementar l'ensenyament-aprenentatge de manera efectiva i que aquest coneixement es podia aplicar a l'aula per tal d'arribar a resultats òptims. Amb el temps, però, es va observar que aquest tipus d'aplicació directa no era ni senzill ni desitjable, ja que el procés d'aprenentatge està influït per una diversitat de variables difícils de controlar en recerques experimentals. Per això, les discussions actuals problematitzen la relació entre la recerca i la pràctica $i$ l'exploren d'una manera crítica i contextualitzada. A grans trets, actualment, es documenten tres posicions principals en les publicacions assagístiques al voltant del tema.

La primera posició és que la recerca en la disciplina de l'ASL té poc a aportar sobre l'ensenyament d'una llengua addicional. La majoria dels estudis que defensen aquesta posició són de finals dels anys 90 i principis del 2000, i alguns els van escriure investigadors que més tard van fer estudis empírics centrats en el tema. En aquests estudis, es donen dues raons principals pel baix impacte de la recerca en ASL en l'ensenyament de llengües addicionals. Primer, els investigadors, d'una banda, i els docents, de l'altra, solen tenir objectius diferents, ja que els investigadors se centren en temes de caire empíric i experimental mentre que els docents es fixen en el que passa a l'aula (Nassaji, 2012). En aquest sentit, fins i tot si s'accepta que l'ASL pot tenir rellevància per a l'ensenyament de llengües, l'ASL s'ha convertit en una disciplina tan diversificada que algunes de les seves línies de recerca ja no pretenen contribuir a l'ensenyament de llengües (Lightbown, 2000; Lacorte, 2013; 2014). Aquest seria el cas, per exemple, de l'estudi de l'adquisició de la sintaxi en el marc generatiu o minimista, un camp fructífer en l'ASL. Segon, els discursos, els mètodes d'investigació i les formes d'informar dels resultats en SLA i DL són marcadament diferents (Nassaji, 2012). Mentre que en el cas de l'ASL la difusió de resultats es fa en forma d'articles a revistes d'investigació indexades, amb avaluacions cegues, en el cas de les publicacions d'ensenyament de llengües la difusió és més àmplia i se sol fer en forma de publicacions per a un públic més gran i divers.

La segona posició és que la recerca en ASL pot ser informativa per a l'ensenyament de les llengües addicionals de diverses maneres. En aquest cas, el focus se centra en la informació que pot aportar la recerca i no en el dictat del que han de fer els docents de llengües addicionals. Els investigadors han justificat aquesta funció informativa sobre la base de tres raons. Primer, els docents poden guanyar agència i desenvolupar les seves identitats docents a mesura que aprenen més sobre ASL i intenten experimentar amb els coneixements d'aquesta disciplina a les seves aules, cosa que els permetrà examinar posteriorment la rellevància potencial de la recerca en la pràctica (Ortega, 2012; Marsden i Kasprowicz, 2017). Segon, tenir coneixements d'ASL pot ser útil per a les expectatives dels professors, és a dir, saber per exemple que els aprenents quan fan activitats en parella no sempre aprenen uns els errors dels altres pot servir per fomentar i justificar aquest tipus d'activitats (Lightbown, 2000; Ellis, 2012; Marsden i Kasprowicz, 2017). O saber que l'aprenentatge de les formes verbals no és lineal sinó dinàmic pot ajudar els docents a tolerar alguns errors recurrents en estadis primerencs (Comajoan i Pérez Saldanya, 2018). Tercer, en els darrers anys, s'ha incrementat la pressió cap als investigadors perquè les seves investigacions tinguin impacte social, la qual cosa ha obligat que la recerca estigui lligada necessàriament amb la millora de les pràctiques (Marsden $\mathrm{i}$ Kasprowicz, 2017).

Finalment, la tercera posició en el debat entre recerca i pràctica és la que podem anomenar de reconceptualització. En concret, a partir de la primera dècada del segle actual s'han configurat noves maneres d'examinar la relació entre la recerca i la pràctica, que han derivat cap a un canvi de la relació, posant èmfasi en les relacions de poder desiguals entre els investigadors i els docents en les diferents disciplines involucrades (unes amb més prestigi i poder que les altres). Aquesta posició va lligada als anomenats turns ("girs") en disciplines relacionades amb temes sociolingüístics (Lacorte, 2013). Des d'aquesta posició - la més allunyada de la idea original aplicacionista - es defensa que no hi ha mètodes tancats per ensenyar llengües ni veritats o prescripcions absolutes provinents de la recerca sinó més aviat principis

${ }^{66}$ Al segle XXI s'han
configurat noves maneres
d'examinar la relació entre
la recerca i la pràctica,
que han derivat cap una
reconceptualització de la
relació, posant èmfasi en les
relacions de poder desiguals
entre els investigadors i
els docents en les diferents
disciplines involucrades
(unes amb més prestigi i
poder que les altres).


per ensenyar i aprendre llengües (Lightbown, 2000; Ellis i Shintani, 2014; The Douglas Fir Group, 2016). A més, es reconeixen les desigualtats de poder de les disciplines $i$ agents — també entre docents i alumnat (Pujolar, 2007) $i$ es reivindica una millora en les condicions d'accés a la recerca, sobretot per als docents (Marsden, Trofimovich, i Ellis, 2019).

Pel que fa a l'ensenyament del català com a llengua addicional per a persones adultes, no es documenten les tres posicions acabades de presentar i la discussió ha girat al voltant de l'aplicació i la rellevància de les diferents teories lingüístiques per a l'ensenyament de llengües i, més en concret, de l'ensenyament de la gramàtica (Cuenca, 1992; 1994; 2000) i al voltant d'aspectes metodològics de l'ensenyament de llengües (per exemple, Julià, 2000 i Cuenca, 1994).

\subsection{Estudis empírics}

Els estudis assagístics van servir de base per a estudis que van començar a examinar la relació entre la recerca i la pràctica seguint una metodologia empírica de recollida i anàlisi de dades provinents dels principals actors en l'ensenyamentaprenentatge de llengües (investigadors, docents, formadors, alumnes, etc.). Aquests estudis han obtingut les dades sobretot mitjançant qüestionaris i s'han interessat en particular per investigar fins a quin punt la recerca ha influït o no en les pràctiques dels docents a l'aula i les raons per les quals això ha passat o no. A continuació fem un repàs breu d'alguns dels estudis més rellevants per emfasitzar-ne la metodologia, el context en què es van dur a terme i els resultats.

Borg $(2009,2013)$ va dissenyar un qüestionari i un estudi de seguiment en què més de 500 professors d'anglès de tot el món van respondre preguntes sobre si llegien recerca en l'ensenyament de llengües i els motius per fer-ho (o no). Els resultats van mostrar que la majoria dels professors $(51,9 \%)$ llegien recerca a vegades i que només el $15,6 \%$ ho feien sovint. Les raons per no llegir recerca eren manca de temps, manca d'accés a publicacions i manca de rellevància pràctica.

Nassaji (2012) va dur a terme un estudi basat en un qüestionari escrit que van contestar 201 professors a Canadà $i$ Turquia. Els resultats van mostrar que la majoria dels professors havien fet cursos d'ASL i que la manca de temps era el motiu principal per no fer recerques pròpies. Pel que fa a l'accés a la recerca, la majoria va esmentar que era fàcil, però això no volia dir que ho fessin (només un 13\% va dir que llegia articles en revistes sovint), sobretot per falta de temps i dificultat per entendre els articles. Finalment, pel que fa a la rellevància $i$ la utilitat de la recerca en ASL per a l'ensenyament a l'aula, la majoria dels professors (79\%) van estar d'acord o estaven totalment d'acord que conèixer la recerca en ASL millorava l'ensenyament de llengües addicionals, però només el $28 \%$ pensava que l'ASL proporcionava suggeriments pràctics per millorar l'ensenyament de la llengua addicional.
Marsden i Kasprowicz (2017) van realitzar dues enquestes en línia i van obtenir 183 i 391 respostes, respectivament, de professors de llengües estrangeres a primària i secundària al Regne Unit. Alguns dels docents feien quasi tota la seva jornada laboral a l'escola (grup anomenat "amb base a l'escola"), mentre que altres no feien tota la jornada a l'escola. Els resultats de les dues enquestes van indicar que els professors amb base a l'escola llegien les investigacions amb menys freqüència (el $60 \%$ van dir que no) que els professors que no tenien base a 1'escola (el 27,1\% van dir que no). Aquests darrers tendien a llegir butlletins o revistes pensades directament per a docents. Els principals factors que van declarar que els impedien participar en la recerca van ser: restriccions pràctiques, accés a la recerca, comprensió de la recerca i percepcions negatives de la recerca.

Muñoz-Basols, Rodríguez-Lifante i Cruz-Moya (2017) van realitzar un estudi amb 1675 professors d'espanyol com a llengua estrangera arreu del món i van trobar que els professors anaven bastant a congressos (39\% van dir que ho feien) i també que feien recerca en ensenyament de llengua $(33,1 \%$ va dir que no en feien), que la recerca era cada vegada més important en el seu perfil docent i que les principals limitacions per no fer més recerca eren la manca de formació, el no reconeixement professional (falta de temps) i la manca de suport de les seves institucions.

Finalment, Sato i Loewen (2018) van estudiar la manera com 12 docents d'anglès com a llengua estrangera a Xile concebien la recerca en llengües addicionals i els obstacles que tenien per aplicar-la a l'aula. Les dades de les entrevistes van mostrar que les perspectives dels docents sobre la recerca eren bastant consistents amb les dels investigadors, és a dir se centraven en el procés d'aprenentatge de la llengua. Pel que fa a la seva actitud cap a la recerca, eren sobretot positives, ja que van expressar que la recerca els semblava rellevant i útil. Pel que fa als obstacles, els més freqüents van ser la manca de temps i les dificultats per trobar suport financer per accedir a la recerca.

La recerca empírica sobre la relació entre recerca i pràctica a l'aula en el cas de l'ensenyament del català no s'ha tractat de manera directa, però sí que es pot entreveure en alguns estudis que aborden temes relacionats. Per exemple, Bastons, Comajoan, Guasch i Ribas (2017) van estudiar les creences del professorat de català sobre l'ensenyament de la gramàtica en els àmbits de primària, secundària (estudi 1) i adults (estudi 2) a partir d'un qüestionari. A l'estudi sobre les creences dels docents de primària i secundària, es va poder observar que el professorat tenia concepcions homogènies sobre els principis per ensenyar gramàtica, però, en canvi, l'homogeneïtat d'idees es perdia en els procediments i pràctiques, que eren molt diversos (entre la tradició aplicacionista i la constructivista). En el cas de l'ensenyament del català com a llengua addicional per a persones adultes, es van obtenir dades de 103 docents $i$ una de les preguntes de recerca de l'estudi era esbrinar les pràctiques docents declarades dels participants. Els resultats van mostrar que hi havia tres tipus de docents: els que se centraven en aspectes normatius, que eren la majoria, els que 
prioritzaven els aspectes comunicatius en l'ensenyament de la gramàtica, $i$ els que eren eclèctics i combinaven diverses perspectives. Aquests perfils, però, no anaven associats de manera clara a les característiques dels docents, com ara la formació, els anys d'experiència o el context laboral.

Comajoan (2015) va investigar fins a quin punt els resultats de la recerca en l'adquisició dels usos dels temps de passat en ASL havien tingut una influència en els llibres de text de català com a llengua addicional. Els resultats van mostrar que si bé es disposa d'una quantitat considerable de resultats de recerca sobre els processos d'adquisició dels usos del passat, aquesta informació no queda reflectida en la manera com es presenten les explicacions gramaticals dels materials d'aprenentatge. Per exemple, la noció d'aspecte, central per a l'adquisició dels usos del passat, apareix poc als llibres de text de català i quan ho fa és de manera ambigua i que fàcilment pot induir a errors. En conclusió, els resultats van mostrar que la rellevància de la recerca en ASL per al disseny de materials d'ensenyament del català havia estat baixa.

La relació entre la recerca i la pràctica en l'ensenyament del català també es pot observar en els estudis sobre formació de docents de llengües addicionals des de la perspectiva constructivista. Per exemple, Esteve, Fernández, MartínPeris i Atienza (2017), tot i que no se centren en docents de català, estudien el procés de formació de docents de llengües addicionals a Catalunya i mostren com l'anomenat enfocament plurilingüe integrat fa possible que els docents transformin les seves creences $\mathrm{i}$ pràctiques al voltant de l'ensenyament de llengües addicionals mitjançant la reflexió i la interacció.

Els estudis de l'àmbit català que acabem de repassar no aborden directament la relació entre recerca i pràctica, però sí que són testimoni de l'interès creixent en les creences del professorat al voltant de les pràctiques que declaren dur a terme a l'aula $\mathrm{i}$ de les seves idees sobre com han de dissenyar les intervencions, que venen mediades per les seves concepcions de la teoria i la recerca.

En resum, els estudis de base empírica sobre la relació entre la recerca i la pràctica han mostrat que, en general, els docents no s'oposen a la idea que la recerca pot tenir un paper en les pràctiques a l'aula. De fet, un nombre

\section{${ }^{66}$ Els estudis de base} empírica sobre la relació entre recerca i pràctica han mostrat que, en general, els docents no s'oposen a la idea que la recerca pot tenir un paper en les pràctiques a l'aula.' considerable de docents creu que la recerca té rellevància per a les seves pràctiques. Aquests estudis també fan palesos els obstacles recurrents amb què es troben els docents, lligats a les condicions laborals (nombre elevat de classes, pagament mediocre) i la consegüent manca de temps, sumada a la dificultat d'accés a la recerca, sigui perquè és de pagament (només accessible a través de bases de dades bibliogràfiques de les universitats) o perquè l'estil retòric es troba massa allunyat del que tenen els docents. Finalment, en el cas de l'ensenyament del català, s'ha documentat que, malgrat que hi ha un acord en les bases teòriques sobre l'ensenyament de llengua (en particular, sobre la gramàtica), les pràctiques declarades a l'aula són molt diverses.

Com s'ha pogut observar en el repàs bibliogràfic que acabem de fer, hi ha escassa recerca empírica sobre la relació entre recerca i pràctica en el cas del'ensenyament del català com a llengua addicional. Per omplir aquest buit es va dissenyar un qüestionari que integrava una pregunta sobre aquest tema, amb l'objectiu de contestar dues preguntes de recerca:

\section{- Els docents de català com a llengua addicional pensen que la recerca en l'ensenyament-aprenentatge de llengües ha influït en la seva pràctica a l'aula?}

- Quines justificacions donen els docents a l'hora de justificar les seves respostes sobre la relació entre la recerca i la pràctica en l'ensenyament del català com a llengua addicional per a persones adultes?

\section{Estudi}

\subsection{Participants}

$\square$ ls participants de l'estudi van ser 76 docents de català com a llengua addicional. La mitjana d'edat era de 43 anys i el 83\% eren dones. El 51\% de docents ensenyaven a un territori de parla catalana i treballaven principalment a centres del Consorci per a la Normalització Lingüística, a Catalunya. El $27 \%$ eren docents a les universitats a l'exterior, principalment a les universitats de la Xarxa de l'Institut Ramon Llull, 15\% eren docents de serveis lingüístics universitaris i el $8 \%$ restant ho eren a escoles oficials d'idiomes. Els participants tenien una mitjana de 14,6 anys d'experiència en l'ensenyament del català i la majoria tenien un nivell alt de formació: el 24\% tenia estudis de llicenciatura relacionats amb l'ensenyament d'idiomes, el 16\% havia fet cursos de postgrau, el 17\% tenia estudis de grau en educació més alguns cursos de temàtiques relacionades amb l'ensenyament de llengües, el 10,5\% tenia un màster i el 24,5\% tenia un grau i a més havia fet cursos de l'àmbit d'ensenyament de llengües. Finalment, la majoria dels participants $(77,5 \%)$ tenien el català com a primera llengua, el 16\% tenien tant el català com el castellà com a L1 i el 6,5\% tenien el castellà com a L1. La recollida de dades 
es va fer durant l'any 2016 mitjançant un qüestionari en línia que es va distribuir a través de l'Institut Ramon Llull, el Consorci per a la Normalització Lingüística i diferents xarxes socials relacionades amb l'ensenyament de llengües.

\subsection{Instrument de recollida de dades i anàlisi}

Les dades de l'estudi provenen d'un estudi més gran que tractava sobre l'ensenyament de les formes i usos del passat en català com a llengua addicional (passat perifràstic, imperfet i perfet). Al final del qüestionari, es va formular una pregunta oberta que tractava el tema que ens ocupa. En concret, la pregunta va ser:

"Des del teu punt de vista, la recerca en ensenyamentaprenentatge de llengües (didàctica de la llengua, pedagogia, adquisició de llengües, etc.) t'ha influït en la teva manera d'ensenyar les formes i els usos del passat? Com t'ha influit? Si no t'ha influit, escriu 'NO'."

Les respostes dels participants es van analitzar seguint la metodologia qualitativa de l'anàlisi de continguts (Krippendorff, 2013). En concret, es va seguir la metodologia dels cicles de codificació qualitativa de Saldaña (2012), que es va adaptar a un procediment de quatre passos. Primer, es van classificar les 76 respostes escrites proporcionades pels participants en un full de càlcul Excel. Segon, es van llegir les respostes posant atenció a les preguntes de recerca $\mathrm{i}$ associant-hi codis descriptius i valoratius emergents (primer cicle de codificació). Tercer, es van rellegir les respostes i els codis emergents i es van recodificar mitjançant la codificació eclèctica (transició entre primer i segon cicle de codificació). Finalment, al segon cicle es va dur a terme una codificació de patrons per reduir el nombre de codis emergents i descriptius i relacionar-los amb les preguntes de recerca. En concret, es van reduir les dades als sis codis que es presenten a la secció de resultats.

\subsection{Resultats}

Els resultats quantitatius van mostrar que el 50\% dels participants van contestar la pregunta sobre la influència de la recerca en les pràctiques a l'aula de manera afirmativa, mentre que el 33\% ho van fer de manera negativa. El 16\% no van contestar la pregunta (Taula 1).

L'anàlisi qualitativa de continguts de les respostes va mostrar que hi havia heterogeneïtat en la manera com els participants van entendre la pregunta $\mathrm{i}$ les respostes que van proporcionar. Amb tot, mitjançant la metodologia qualitativa d'anàlisi es van reduir els resultats als sis continguts principals següents, de més a menys freqüent: 1) formació en general, 2) cerca de bibliografia, 3) metodologia d'ensenyament, 4) relació explícita recerca-pràctica, 5) experiència personal i 6) manca de relació entre la recerca i la pràctica en l'ensenyament de llengües.

\begin{tabular}{lcc}
\hline Resposta & Freqüència & Percentatge \\
\hline Sí justificat & 37 & $49 \%$ \\
"Sí" & 1 & $1 \%$ \\
No justificat & 5 & $7 \%$ \\
"No" & 20 & $26 \%$ \\
"No ho sé" & 1 & $1 \%$ \\
Sense resposta & 12 & $16 \%$ \\
\hline Total & $\mathbf{7 6}$ & $\mathbf{1 0 0} \%$ \\
\hline
\end{tabular}

Taula 1. Respostes a la pregunta sobre la influència de la recerca en la manera d'ensenyar llengües

\section{1) Formació en general}

Un nombre considerable de docents van contestar la pregunta sobre la rellevància de la recerca fent referència a la seva formació en general, però sense parlar directament del tema de la recerca. En aquest cas, els docents es van centrar sobretot a fer esment de la influència de l'enfocament comunicatiu en la seva manera d'ensenyar:"7

(1) "Sí, he après a ensenyar des del punt de vista comunicatiu".

(2) "M'ha influït l'enfocament comunicatiu".

(3) "Sí. A fer un ensenyament més comunicatiu i sobre tot a fer-ho des dels interessos dels alumnes. Al menys intentar-ho!"

(4) "Sí que m'ha influït, sobretot quan vaig aprendre l'enfocament comunicatiu per tasques. Ha sigut molt positiu".

\section{2) Cerca de bibliografia}

Alguns docents van afirmar que, motivats pel fet que havien d'ensenyar temes difícils (passats i subjuntiu, per exemple), havien buscat bibliografia sobre com ensenyar-los. Cal fer notar que les referències que van esmentar els docents no eren de didàctica del català, sinó que se solien centrar en l'ensenyament de l'espanyol com a llengua estrangera o l'anglès:

(5) "Sí. Crec que al llarg dels anys, l'ensenyament dels passats (i del subjuntiu) és el que més m'ha portat a consultar bibliografia o mirar manuals d'altres llengües, fins i tot les gramàtiques d'anglès (la col·lecció de Cambridge classificades per nivell), per veure diversos enfocaments".

(6) “Sí que m'ha influït. He llegit bibliografia sobre els passats $\mathrm{i}$ hi he reflexionat. M'agrada pensar-hi, però intentar que els estudiants assimilin el punt de vista 
gramatical no em funciona perquè s'emboliquen. Cada estudiant té una L1 diferent $i$ ha de fer seva la comparació amb el català. És l'ús comunicatiu de la llengua el que demostra si el fan servir bé. Quan els comentes els seus errors és quan n'aprenen".

Alguns docents van fer referència explícita a algunes obres de bibliografia que els van influir. En concret, van esmentar la influència de la gramàtica cognitiva en l'ensenyament de llengües (i dels temps verbals) i en particular al cas de l'espanyol com a llengua estrangera:

(7) “Sí, m’han influït positivament les recerques sobre gramàtica cognitiva (aplicades bàsicament a l'espanyol L2)".

(8) "Sí. M'ha ajudat molt el bagatge en didàctica de l'espanyol ELE".

(9) “Sí. M'han influït molt els treballs i les publicacions per al castellà dels investigadors de Granada (Castañeda, Ruiz Campillo, etc.)”.

En aquest cas, és destacable l'impacte que ha tingut la gramàtica cognitiva en l'ensenyament del castellà com a llengua addicional, sobretot a partir de l'obra i els autors que esmenten alguns dels participants (per exemple, la Gramática bàsica del estudiante de español, Alonso et al., 2011). L'impacte de la gramàtica cognitiva en l'ensenyament d'altres llengües també ha estat considerable però en menor grau que en el cas de l'espanyol (vegeu-ne un repàs a Comajoan i Llop, 2021).

\section{3) Metodologia d'ensenyament}

Alguns docents van donar evidències de com concebien la recerca i no van destacar un tema sobre els altres sinó que van donar exemples que incloïen teories lingüístiques (per exemple, l'anàlisi contrastiva), aspectes teoricometodològics (tasques), aspectes de gestió d'aula i el disseny de materials.

(10) "Sí. El coneixement de lingüística contrastiva, la realització de tasques, la necessitat de focalitzar-se en la comunicació, etc. contribueixen a facilitar la creació de materials".

(11) "No m'han influenciat concretament en la manera d'ensenyar les formes i els usos del passat, tot i que el llibre Gramàtica pràctica del català m'ha servit de gran ajut a l'hora de plantejar aquesta qüestió. Tanmateix, en un àmbit més general d'enfocament de les classes, sí que m'han influenciat els plantejaments del mètode comunicatiu i el de gramàtica i traducció".

(12) “Suposo que sí que m'ha influït, tot i que no sabria explicar com. La meva manera d'explicar les formes i els usos del passat ha anat canviant a mesura que he fet cursos sobre ensenyament $i$ aprenentatge de la llengua, que he parlat $\mathrm{i}$ compartit experiències $\mathrm{amb}$ altres professors, que m'he adonat de les dificultats amb les quals m'he trobat a l'aula, etcètera. Entenc que les influències provenen de molts llocs".

\section{4) Relació explícita recerca-pràctica}

Van ser pocs els docents que van donar detall en les seves respostes sobre el tema central que es demanava, és a dir la influència de la recerca en la pràctica, $i$ quan ho van fer ho van relacionar amb l'enfocament comunicatiu, amb la formació i la seva aplicació a l'aula, en molts casos també centrat en l'ensenyament de l'espanyol com a llengua estrangera.

(13) "Fa uns quants anys que vaig acabar el màster (de formació de professors d'ELE). En aquell moment, tot el que vaig llegir, sobretot sobre metodologia a l'hora d'ensenyar llengües estrangeres, em va influir molt. Em va influir en el sentit que ensenyem llengua amb la finalitat de comunicar-nos i per això cal una reflexió a l'hora d'escollir un o altre passat. A classe poso un exemple que em sembla molt il·lustratiu d'una cançó del grup Manel que diu: 'Vam conversar, vam riure $i$ hem fet l'amor'. Per què canvia el temps en aquest últim verb? És només per una qüestió temporal?"

(14) "Sí. Em va ajudar molt el curs de didàctica de la International House, en què vam tractar l'ensenyament de les formes i els usos del passat".

\section{5) Experiència personal}

Alguns docents van contestar la pregunta sobre la influència de la recerca relacionant-la amb la seva pràctica, centrada amb els alumnes i l'aula, i van donar respostes que apel·laven a la centralitat de l'aprenent en el procés d'ensenyament de llengües:

(15) 'El que m'ha influït és la manera com s'expressen els estudiants i les seves preguntes. A partir d'això, vaig refent la manera d'ensenyar el passat'.

(16) “Sí, en el sentit que la reflexió ha de provenir de l'ús que se'n fa. Cal crear situacions en què l'alumnat s'enfronti a la necessitat d'utilitzar els diferents passats".

(17) “Sí que m’ha influït. Si el que volem és donar una eina per comunicar-se bé, m'he programat el curs d'acord amb les necessitats de l'aprenent".

La centralitat de l'alumne i les situacions concretes d'aula es relacionen també amb la importància que van donar molts participants a la seva experiència com a docents. Cal destacar, però, que aquesta noció d'experiència no es 
relaciona directament amb el que es demanava a la pregunta, és a dir la relació entre la recerca i la pràctica:

(18) "L'experiència és l'única cosa que m’ha influït".

(19) “La influència m'ha vingut donada sobretot per l'experiència".

(20) "M'ha influït sobretot la meva experiència com a aprenent de segones llengües. L'anàlisi de les meves pròpies dificultats m'ajuden a entendre les dels alumnes i a buscar estratègies per resoldre-les".

(21) "Crec que la forma en què he après altres llengües (francès, alemany) m'ha influït en la manera en què l'explico als alumnes".

(22) "Sí, perquè compares amb la pròpia experiència en l'aprenentatge d'una L2 i perquè busques maneres d'aprendre-ho de manera fàcil si és un nivell inicial. A mesura que el nivell és més alt, aportes més informació (altres usos...)".

\section{6) Manca de relació entre recerca i pràctica en l'ensenyament de llengües}

Finalment, tal com s'indicava a les instruccions, si la resposta era negativa, calia escriure "no". Alguns docents van ampliar la resposta negativa i la van justificar:

(23) "No, perquè en els nombrosos cursos de didàctica que he fet, mai no han tocat aquest tema. De fet, crec que hi ha una carència importantíssima en la formació continuada del professorat pel que fa a didàctica de la llengua pel que fa a temes concrets. Vaig estudiar filologia catalana".

(24) 'No, per a aquesta part de l'ensenyament, la recerca en ensenyament-aprenentatge de llengües no m'ha ajudat gaire".

(25) "No, però tampoc nego que pugui ser així. En el meu cas, no ha estat així".

D'aquestes respostes negatives cal destacar que alguns docents van declarar que havien rebut formació en didàctica de llengües, però no per a l'ensenyament de temes concrets, com, per exemple, les formes i usos dels passats en català. Altres participants que van expandir la seva resposta negativa van fer referència a la dificultat de trobar la recerca sobre un tema concret:

(26) "La veritat és que poc, potser perquè no he trobat/ buscat gaires estudis que m'aportaren informació rellevant per a les meues classes".

\section{Discussió dels resultats}

es preguntes de recerca que s'ha plantejat aquest article són dues. La primera pretenia esbrinar fins a quin punt els docents de català com a llengua addicional declaraven que la recerca en ensenyament-aprenentatge de llengües havia influït o no en les percepcions de la seva manera d'ensenyar $i$, més en concret, en com ensenyaven les formes i els usos del passat. Els resultats de l'estudi han mostrat que la meitat dels docents pensaven que havien rebut alguna influència de la recerca, la qual cosa és notable, ja que indica que la recerca té una rellevància que podem considerar mitjana. També és de destacar que un terç (33\%) dels participants va contestar negativament la resposta. Aquests resultats no es desvien gaire dels estudis precedents, en què hi sol haver un nombre alt de docents que afirmen que la recerca els ha influït i la consideren rellevant per a la seva tasca de docència (Muñoz-Basols, Rodríguez-Lifante i CruzMoya, 2017; Nassaji, 2012; Sato i Loewen, 2018).

La segona pregunta intentava aprofundir en les justificacions que van donar els docents sobre la influència o manca d'influència de la recerca en la seva percepció de la pràctica d'ensenyament del català a persones adultes. Tal com s'ha observat en les respostes dels participants, la influència no es concreta gaire i s'hi observen algunes tendències. En destaquem tres.

En primer lloc, els docents tendeixen a associar recerca amb un enfocament concret per ensenyar llengües addicionals, el comunicatiu, i l'impacte que va tenir en la seva formació. De les respostes dels docents se'n desprèn que no hi ha un coneixement profund de la recerca al voltant de l'enfocament comunicatiu ja que cap dels participants va esmentar obres, autors o idees concretes sobre la recerca en didàctica i l'enfocament comunicatiu, i encara menys en l'àmbit del català com a llengua addicional. Aquest resultat pot estar relacionat amb el fet que arran de l'adopció de l'enfocament comunicatiu per ensenyar llengües addicionals, i el seu èmfasi en l'aprenentatge a partir de l'exposició a l'input, es va tendir a menystenir l'ensenyament de la gramàtica explícita $\mathrm{i}$, de retruc, a menystenir la necessitat d'estudiar i aportar evidències sobre els processos d'ensenyament explícits. 
Un factor que també pot haver contribuït al resultat sobre la poca familiaritat de molts dels docents amb la recerca és que la divulgació de la recerca als territoris de parla catalana i a l'Estat espanyol — per part de les universitats i altres organismes - encara no està consolidada i sovint hi ha dificultats de crear ponts entre investigadors (universitaris) i docents fora de la universitat. D'altra banda, és destacable que sí que es van esmentar obres i autors concrets de referències de l'ensenyament de l'espanyol com a llengua estrangera $\mathrm{i}$ en concret de la influència de la gramàtica cognitiva. També hi va haver una referència a la Gramàtica pràctica del català (Bastons, Bernadó, i Comajoan, 2011), tot i que no es pot considerar una referència de recerca en ensenyament de gramàtica. En aquest sentit, els docents sembla que fan referència a recursos concrets per dissenyar les seves intervencions més que no pas a temes de recerca.

En segon lloc, és bastant freqüent en les respostes dels participants la idea que hi ha altres aspectes tant o més importants que la recerca i se'n singularitzen dos de concrets: l'alumnat i l'experiència del docent. Aquestes respostes fan evident que malgrat que els docents declaren que la recerca ha tingut influència en la seva pràctica, en general, donen més importància a l'experiència i a la situació d'aula que no pas a la recerca. Això queda reflectit en algunes respostes properes a l'escepticisme vers la recerca i també en les respostes negatives.

Finalment, a diferència d'altres estudis que aborden el tema de la influència de la recerca en la pràctica (Muñoz-Basols, Rodríguez-Lifante i Cruz-Moya, 2017; Nassaji, 2012; Sato i Loewen, 2018), en les respostes dels participants d'aquest estudi no es va fer referència a alguns dels obstacles recurrents en estudis previs, com ara la manca de temps i les dificultats d'accés a la recerca. Aquest resultat pot ser fruit de la metodologia de l'estudi, centrat en una pregunta que fa referència a l'ensenyament d'un tema concret (formes i usos dels passats). Alguns participants és probable que no estiguessin familiaritzats amb la recerca en aquesta àrea concreta i per això no van expressar els obstacles per accedirhi i van centrar-se més en temes generals sobre recerca i pràctica, com ara l'enfocament comunicatiu.

A part del que acabem d'esmentar, aquest estudi presenta algunes limitacions que s'haurien de tenir en compte en recerques futures. Pel que fa a la mostra de l'estudi, és petita, considerant la quantitat de docents que hi ha tant a territoris de parla catalana com a fora. En aquest sentit, caldria un estudi de més abast en el futur que tingués una mostra més gran i representativa del col-lectiu de docents. Pel que fa a la metodologia de l'estudi, caldria avaluar l'impacte que va tenir fer la pregunta sobre la influència de la recerca relacionantla amb el tema de l'ensenyament de les formes i usos del passat. Centrar la pregunta en un tema concret té l'avantatge que obliga els docents a reflexionar sobre la pregunta de la influència de la recerca en la pràctica de manera precisa, però alhora té l'inconvenient que limita les respostes, ja que podria donar-se el cas que la recerca ha influït els docents en altres aspectes més enllà del que es focalitza. Per això, caldria dur a terme estudis que profunditzessin en la relació entre recerca i pràctica des de diverses perspectives.

\section{Conclusió}

E n aquest article s'ha fet evident que avui dia gaudim d'un bagatge considerable de recerca al voltant de la influència de la recerca en l'ensenyament de llengües addicionals. Els resultats de l'estudi han mostrat que els docents de català per a persones adultes afirmen que la recerca els ha influït, tot $\mathrm{i}$ que les influències que esmenten són més aviat generals i poc centrades en temes de recerca en didàctica de la llengua catalana. Aquests resultats ens porten a fer una reflexió al voltant de la relació entre la recerca i la pràctica en l'ensenyament del català com a llengua addicional per a persones adultes. Els resultats sobre la poca influència concreta de la recerca en l'ensenyament de la llengua catalana mostren que el camp de la didàctica del català encara no està prou desenvolupat o que si ho està no ha acabat de tenir un impacte en la comunitat educativa dels docents de català per a persones adultes. Aquest fet probablement té a veure amb la poca consolidació que té la recerca en didàctica del català per a persones adultes. En canvi, la recerca en didàctica de la llengua en entorns d'ensenyament obligatori a infants $i$ joves (infantil, primària i secundària) està consolidada. En el camp de l'ensenyament del català a persones adultes hi ha un nombre molt alt de docents, aprenents i entorns on s'ensenya, però encara no hi ha un nombre suficient d'investigadors $i$ docents que facin recerca al voltant del català. En el futur seria desitjable que la recerca en català com a llengua addicional creixés i es consolidés. Aquí apuntem breument tres maneres d'augmentar la massa crítica d'investigadors $i$ fer avançar el camp de la didàctica del català per a persones adultes.

Primer, cal aprofitar el relleu generacional d'investigadors $\mathrm{i}$ docents per generar interès en recerca en didàctica de la llengua catalana en el context de l'aprenentatge de la llengua per part de persones adultes. Aquest relleu generacional es pot observar de mica en mica en organitzacions com l'Associació de Joves Investigadors en Llengua i Literatura Catalanes, la Societat d'Ensenyament i Recerca del Català com a Llengua Estrangera (SERCLE) i també en noves publicacions, com ara Resercle. ${ }^{8}$ Amb l'interès per part dels investigadors no n'hi ha prou. Per això, és important que les institucions educatives dels diferents territoris de parla catalana també s'impliquin en la recerca en l'ensenyamentaprenentatge de la llengua catalana i col-laborin per fer possible un ensenyament més basat en la recerca i l'evidència científica.

Segon, caldria consolidar les iniciatives que hi ha de formació en didàctica del català per a persones adultes, com ara cursos, postgraus i màsters, $i$ assegurar que els continguts de la formació combinen aspectes de recerca i pràctica. ${ }^{9}$ En aquest sentit, caldria fomentar punts de contacte entre investigadors, docents, autors de materials didàctics i la resta d'agents involucrats en l'ensenyament de llengües.

Finalment, seria beneficiós per al camp de la didàctica de la llengua catalana per a persones adultes integrar la recerca en l'aprenentatge del català dins de grups de recerca de didàctica de la llengua catalana ja consolidats i centrats en 
edats escolars (per exemple, primària i secundària). Una altra possibilitat seria integrar l'estudi de la didàctica del català a grups de recerca que estudien l'ensenyament-aprenentatge de llengües estrangeres (sobretot, l'anglès). D'aquesta manera es podria aprofitar l'experiència investigadora en un context i ampliar-lo al de l'ensenyament del català com a llengua addicional per a persones adultes.

Esperem que en els propers anys investigadors novells $i$ experimentats aprofitin tot el bagatge d'ensenyament $i$ recerca en llengua catalana, com el que s'inclou en aquest monogràfic, per tal de consolidar la recerca en didàctica de la llengua catalana per a persones adultes i avançar en el procés d'ensenyament-aprenentatge de la llengua.

\section{Notes}

1 Expressem el nostre agraïment a les persones que van participar en l'estudi que es presenta en aquest article i a les persones que van participar en la distribució de l'enquesta en línia: Joana Álvarez (Escola Oficial d'Idiomes Barcelona-Drassanes), Carme Bové (Consorci per a la Normalització Lingüística) i Ignasi Massaguer (Institut Ramon Llull). També expressem l'agraïment als quatre avaluadors anònims de l'article per les valuoses aportacions que hi han fet.

2 Sovint la disciplina s'anomena didàctica de la llengua i la literatura, ja que l'ensenyament de la llengua i la literatura van estretament lligades, sobretot en entorns d'educació obligatòria. Per raons d'espai, en aquest article ens centrem en l'ensenyament de la llengua.

3 En aquest sentit, és útil recordar la distinció que fa l'OECD (2015, p. 29) entre recerca bàsica, aplicada i experimental: "Basic research is experimental or theoretical work undertaken primarily to acquire new knowledge of the underlying foundation of phenomena and observable facts, without any particular application or use in view. Applied research is original investigation undertaken in order to acquire new knowledge. It is, however, directed primarily towards a specific, practical aim or objective. Experimental development is systematic work, drawing on knowledge gained from research and practical experience and producing additional knowledge, which is directed to producing new products or processes or to improving existing products or processes".

4 En llengua anglesa, l'equivalent a didàctica de la llengua sol ser "language teaching" o "language pedagogy". Per això, sovint en llengües romàniques també trobem "ensenyament de llengües" com a sinònim de "didàctica de la llengua". En anglès, existeix el terme didactics, però sol tenir una connotació negativa centrada quasi exclusivament en la transmissió de coneixement. En altres llengües romàniques, es fan servir els termes didáctica de la lengua (castellà), didactique de la langue (francès) i didattica della lingua (italià), tot i que en italià han proliferat altres etiquetes (glottodidattica, glottodidattica sperimentale, linguistica acquisizionale $\mathrm{i}$ didattica acquisizionale, Rastelli, 2019; Chini, 2016).

5 Vegeu Comajoan (2003; 2008), Ellis (2008; 2020), Ellis i Shintani (2014), De Santiago i Fernández (2017) i Muñoz-Basols, Gironzetti i Lacorte (2019) per a una història de la disciplina en els àmbits del català, l'anglès i el castellà.

6 Per exemple, en l'àmbit català, la recerca sobre la intervenció didàctica en l'ensenyament de llengües a l'aula es tracta regularment en diferents jornades $\mathrm{i}$ congressos, com ara el seminari internacional 'L'aula com a àmbit d'investigació sobre l'ensenyament i l'aprenentatge de llengües", celebrat bianualment (2019, Universitat Autònoma de Barcelona, https://jornades. uab.cat/9seminari/ca; 2017, Universitat de Vic, https:// mon.uvic.cat/aula-investigacio-llengua/organitzacio/).

7 Les cites dels participants es presenten senceres, és a dir no s'han editat en la seva llargada. S'han corregit les errades d'ortografia i els errors de picatge.

8 Resercle és la revista de la Societat de l'Ensenyament i Recerca en Català com a Llengua Estrangera. Publica articles de recerca, activitats didàctiques, textos de l'alumnat, entrevistes i ressenyes. És d'accés lliure i es pot consultar a https://www.sercle.cat/web/resercle/.

9 En l'actualitat hi ha una oferta considerable de formació de professorat de català per a persones adultes: Postgrau d'ensenyament de català per a persones adultes (Universitat de Vic, Universitat de Barcelona i Universitat Autònoma de Barcelona, https://www. uvic.cat/formacio-continua/ca/masters-i-postgraus/ educacio-i-societat/ensenyament-de-catala-personesadultes), Màster en ensenyament d'espanyol i de català com a segones llengües (Universitat de Girona, https:// www.udg.edu/ca/masters-en-humanitats/Ensenyamentde-lEspanyol-i-el-Catala), Màster d'ensenyament d'espanyol/català per a immigrants (Universitat de Lleida, http://www.master-ele-o-cle-immigrants.udl.cat/ $\mathrm{ca} /)$, Jornades Internacionals de didàctica del català com a L2 (SERCLE), Curs d'introducció a la didàctica de la llengua com a idioma estranger (Institut Ramon Llull, Acadèmia Valenciana de la Llengua i Xarxa Vives d'Universitats), Jornades Internacionals per a Professorat de Català (Institut Ramon Llull), Jornades Multilingües de l'Escola d'Idiomes Moderns (UB), Jornada Aprendre Llengües al Segle XXI (Consorci per a la Normalització Lingüística) i Trobada d'actualització de didàctica de llengües estrangeres (Universitat Autònoma de Barcelona i Escola Oficial d'Idiomes Barcelona-Drassanes). 


\section{Referències}

Aguilar, C. (2001). Didàctica del català i pedagogia crítica. Publicacions de la Universitat Jaume I.

Alonso, R., Castañeda, A., Martínez, P., Miquel, L., Olivares, J., i Ruiz J. P. (2011). Gramática básica del estudiante de español (2a. ed.). Difusión.

Bastons, N., Bernadó, C., i Comajoan, L. (2011). Gramàtica pràctica del català. Teide.

Bastons, N., Comajoan, L., Guasch, O., i Ribas, T. (2017). Les creences del professorat sobre l'ensenyament de la gramàtica a l'aula: cap a una tipologia de docents. Caplletra, 63, 139-164.

https://doi.org/10.7203/caplletra.63.10397

Borg, S. (2009). English language teachers' conceptions of research. Applied Linguistics, 30, 355-388.

Borg, S. (2013). Teacher research in language teaching. Cambridge University Press.

Bori, P. (2020). La enseñanza del catalán en el mundo y la catalanística internacional. Анали Филолошког факултета, 32.

https://doi.org/10.18485/analiff.2020.32.1.14.

Camps, A. (2000). Introducció: objecte, modalitats i àmbits de la recercaendidàctica de la llengua. Dins A. Camps, I. Ríos i M. Cambra (Eds.), Recerca i formació en didàctica de la llengua (pp. 9-22). Graó.

Camps, A. (2012). La investigación en didáctica de la lengua en la encrucijada de muchos caminos. Revista Iberoamericana de Educación, 59, 23-41.

https://doi.org/10.35362/rie590455

Camps, A., Ríos, I., i Cambra, M. (Eds.). (2000). Recerca $i$ formació en didàctica de la llengua. Graó.

Chini, M. (2016). Elementi utili per una didattica dell'italiano L2 alla luce della ricerca acquisizionale. Italiano Lingua Due, 2, 1-18.

Comajoan, L. (1999). Mètodes, teoria i ensenyament de llengües estrangeres: una relació complexa. Llengua i ús, 14, 45-53.

Comajoan, L. (2003). Adquisició de primeres i segones llengües: perspectiva històrica $\mathrm{i}$ qüestions actuals. Caplletra, 35, 15-46.

Comajoan, L. (2004). La relació entre la teoria de l'adquisició de segones llengües i l'ensenyament de llengües: com ens podem avenir? Dins A. Fargas i T. Puntí (Eds.), Actes del 3r Simposi sobre l'ensenyament del català a no catalanoparlants. Eumo.

Comajoan, L. (2015). L'adquisició i l'ensenyament dels usos del passat: anàlisi de manuals de català com a segon llengua. Zeitschrift für Katalanistik: Revista d'Estudis Catalans, 28, 283-306.

Comajoan, L., i Llop, A. (2021). An SLA-informed and cognitive linguistic approach to the teaching of L2 Catalan tense-aspect. Círculo de Lingüística Aplicada a la Comunicación.

Comajoan, L., i Pérez-Saldanya, M. (2018). Los tiempos verbales del español. Descripción del sistema y su adquisición en segundas lenguas. Octaedro.

Cuenca, M. J. (1992). Teories gramaticals i ensenyament de llengües. Tàndem.

Cuenca, M. J. (1994). (Ed.). Lingüística i ensenyament de llengües. Universitat de València.

Cuenca, M. J. (2000). Lingüística teòrica i lingüística aplicada a l'ensenyament de llengües. Dins J. Julià (Ed.), L'ensenyament del català com a L2. De la teoria a la pràctica (pp. 35-50). Universitat de Lleida.

De Santiago, J., i Fernández, J. (2017). Fundamentos para la enseñanza del español como 2/L. Arco.

DeKeyser, R. (2010). Where is our field going? The Modern Language Journal, 94, 646-647.

DeKeyser, R., i Prieto Botana, G. (Eds.). (2019). Doing $S L A$ research with implications for the classroom. John Benjamins.

Dolz, J., Gagnon, R., i Mosquera, S. (2009). La didáctica de las lenguas: una disciplina en proceso de construcción. Didáctica, Lengua y Literatura, 21, 117-141.

Ellis, R. (1991). Instructed second language acquisition. Wiley-Blackwell.

Ellis, R. (2008). The study of second language acquisition (2a. ed.). Oxford University Press.

Ellis, R. (2012). Language teaching research and language pedagogy. Wiley-Blackwell.

Ellis, R. (2020). A short history of SLA: Where have we come from and where are we going? Language Teaching, $54,1-16$.

https://doi.org/10.1017/S0261444820000038 
Ellis, R., i Shintani, N. (2014). Exploring language pedagogy through second language acquisition research. Routledge.

https://doi.org/10.4324/9780203796580

Esteve, O. (2011). Desenvolupant la mirada investigadora a l'aula. La pràctica reflexiva: eina per al desenvolupament professional com a docent. Dins A. Camps (Coord.), Llengua catalana i literatura: investigació, innovació i bones pràctiques (pp. 27-46). Graó

Esteve, O. (2013). Entre la práctica y la teoría. Comprender para actuar. Ikastaria, 19, 13-36.

Esteve, O., Fernández, F., Martín-Peris, E., i Atienza, E. (2017). The Integrated Plurilingual Approach: A didactic model providing guidance to Spanish schools for reconceptualizing the teaching of additional languages. Language and Sociocultural Theory, 4, https://journals. equinoxpub.com/OLDLST/article/view/32868

https://doi.org/10.4324/9780203796580

Gimeno, M. (2007). La formació del professorat de català per a adults. Llengua i ús: revista tècnica de política lingüistica, 39, 51-55.

Gimeno, M. (2012). La Direcció General de Política Lingüística i l'ensenyament de català per a adults. La perspectiva històrica, 1. L'enfocament comunicatiu i els processos d'innovació. Llengua i ús: revista tècnica de política lingüística, 51, 3-13.

Housen, A., i Pierrard, M. (2005). Investigations in instructed second language acquisition. Mouton de Gruyter. https://doi.org/10.1515/9783110197372.0.1

Julià, J. (2000). (Ed.). L'ensenyament del català com a L2. De la teoria a la pràctica. Universitat de Lleida.

Krippendorff, K. (2013). Content analysis: An introduction to its methodology. Sage.

Lacorte, M. (2013). Planteamientos ecológicos para la metodología del español como L2. Miríada Hispánica, $6,17-32$.

Lacorte, M. (2014). Methodological approaches and realities. Dins M. Lacorte (Ed.), The Routledge handbook of Hispanic applied linguistics (pp. 99-116). Routledge.

Lacueva, M. (2017). Didàctica de la cultura a la universitat: dels estudis culturals als estudis catalans (i viceversa). Dins M. Lacueva (ed.), Didàctica universitària dels estudis culturals. Pràctiques $i$ tendències en la Catalanística i la Hispanística (p. 101-128). Saarland University Press. https://doi.org/10.31009/resercle.2020.i1.14

Leow, R. (2015). Explicit learning in the L2 classroom: A student-centered approach. Routledge.

Leow, R., i Cerezo, L. (2016). Deconstructing the I and SLA in ISLA: One curricular approach. Studies in Second Language Learning and Teaching, 6, 43-63.

https://doi.org/10.14746/ssllt.2016.6.1.3

Lightbown, P. (2000). Classroom SLA research and second language teaching. Applied Linguistics, 21, 431-462.

https://doi.org/10.1093/applin/21.4.431

Loewen, S. (2020). Introduction to instructed second language acquisition (2a ed.). Routledge.

Loewen, S., i Sato, M. (2019). Instructed second language acquisition and English language teaching: theory, research, and pedagogy. Dins X. Gao (Ed.), Second handbook of English language teaching (pp. 1-19). Springer.

https://doi.org/10.1007/978-3-030-02899-2_60

Long, M. (2017). Instructed second language acquisition (ISLA): geopolitics, methodological issues, and some major research questions. Instructed Second Language Acquisition, 1, 7-44.

https://doi.org/10.1558/isla.33314

López Valero, A., i Encabo Fernández, E. (2013). Fundamentos didácticos de la lengua y la literatura. Síntesis.

Marsden, E., i Kasprowicz, R. (2017). Foreign language educators' exposure to research: Reported experiences, exposure via citations, and a proposal for action. The Modern Language Journal, 101, 613-642.

https://doi.org/10.1111/modl.12426

Marsden, E., Trofimovich, P., i Ellis, N. (2019). Extending the reach of research: Introducing Open Accessible Summaries at Language Learning. Language Learning, $69,11-17$.

https://doi.org/10.1111/lang.12337

Mendoza, A., i Cantero, F. J. (2013). Didáctica de la lengua y de la literatura: aspectos epistemológicos. Dins A. Mendoza (Ed.), Didáctica de la lengua y la literatura (pp. 3-26). Prentice Hall.

Muñoz-Basols, J., Gironzetti, E., i Lacorte, M. (Eds.). (2019). The Routledge handbook of Spanish language teaching. Routledge.

https://doi.org/10.4324/9781315646169 
Muñoz-Basols, J., Rodríguez-Lifante, A., i Cruz-Moya, O. (2017). Perfil laboral, formativo e investigador del profesional de español como lengua extranjera o segunda (ELE/EL2): Datos cuantitativos y cualitativos. Journal of Spanish Language Teaching, 4, 1-34.

https://doi.org/10.1080/23247797.2017.1325115

Nassaji, H. (2012). The relationship between SLA research and language pedagogy: Teachers' perspectives. Language Teaching Research, 16, 337-365.

https://doi.org/10.1177/1362168812436903

OECD (2015). Frascati Manual 2015. Guidelines for collecting and reporting data on research and experimental development. OECD.

https://doi.org/10.1787/9789264268111-ko

Ortega, L. (2012). How relevant is SLA research for language teaching? Choosing between application and relevance. Dins B. Hinger, E. M. Unterrainer, i D. Newby (Eds.,), Sprachen Lernen? (pp. 24-38). Praesens Verlag.

Ortega, L. (2015). Second language learning explained? SLA across 10 contemporary theories. Dins B. Van Patten, B., i J. Williams, J. (Eds.), Theories in second language acquisition: An introduction (2a. ed., pp. 245272). Routledge.

Pujolar, J. (2007). African women in Catalan language courses: Struggles over class, gender and ethnicity in advanced liberalism. Dins B. McElhinny (ed.), Words, worlds and material girls: Language, gender, global economies (pp. 305-347). Mouton de Gruyter.

https://doi.org/10.1515/9783110198805.3.305

Rastelli, S. (2009). Che cos'è la didattica acquisizionale. Il Mulino.

Rastelli, S. (2019). Introduzione alla glottodidattica sperimentale. Il Mulino.

Saldaña, J. (2012). The coding manual for qualitative researchers ( $2 \mathrm{a}$ ed.). Sage.

Sato, M., i Loewen, S. (2018). Do teachers care about research? The research-pedagogy dialogue. ELT Journal, $73,1-10$.

https://doi.org/10.1093/elt/ccy048

Sato, M., i Loewen, S. (Eds.). (2019). Evidence-based second language pedagogy. Routledge.

Simard, C., Dufays, J.-C., Dolz, J., i Garcia-Debanc, C. (2010). Didactique du français langue première. De Boeck.

https://doi.org/10.3917/dbu.simar.2010.01
The Douglas Fir Group. (2016). A transdisciplinary framework for SLA in a multilingual world. The Modern Language Journal, 100, 19-47.

https://doi.org/10.1111/modl.12301

Van Patten, B., Keating, G., i Wulff, S. (2020). Theories in second language acquisition. Routledge. 